\title{
Suggestopedic research in the GDR Sigrid Gassner-Roberts
}

\begin{abstract}
At the Institute of Mnemology at the University of Leipzig, a research team consisting of faculty members from the departments of Medicine, Education, Music and Psychology, as well as laboratory technicians has been investigating suggestopedic teaching for several years. English and Spanish language courses are conducted on a regular basis in connection with this research. The results of the research have been published in "Wissenschaftliche Berichte". This article describes a visit to the Institute, an observation of a Spanish lesson, and provides a summary of two articles from the "Wissenschaftliche Berichte".
\end{abstract}

By die Instituut vir Geheue-ontwikkeling aan die Universiteit van Leipzig word suggestopediese onderrig reeds verskeie jare nagevors deur 'n span saamgestel uit lede vanuit die departemente van Geneeskunde, Opvoedkunde, Musiek en Sielkunde, tesame met 'n aantal laboratoriumtegnici. Taalkursusse in Engels en Spaans word gereeld aangebied as deel van die navorsingsprogram. Die resultate wat tot dusver behaal is, is gepubliseer in "Wissenschaftliche Berichte". Met hierdie artikel word 'n besoek aan die Instituut vir Geheueleer beskryf, sowel as 'n waarneming van 'n Spaanse les. Ten slotte word 'n opsomming gegee van twee van die artikels wat in "Wissenschaftliche Berichte" verskyn het.

In October 1984 I had the privilege of visiting the University of Leipzig in the German Democratic Republic. Dr Klaus Jänicke, a neurologist and psychiatrist, is the director of the research division for mnemology. In the course of my discussions with Dr Jänicke I found out that suggestopedic language teaching and all experiments regarding mnemology are conducted in another building on the outskirts of the city. Every week all teachers and researchers, and on occasion the technicians, meet in Dr Jänicke's office to present and discuss progress reports and decide on directives regarding teaching and research. The members of this team include, in addition to the director a music therapist, a psycho-physiologist, an educationalist, several language and anatomy teachers, all of them with an extensive knowledge of psychology, and several laboratory technicians. I was shown the laboratories where EEG, ECG and all kinds of bio-feedback measurements are taken. Students who take suggestopedic courses at the University are often put under laboratory conditions for specific purposes, for example for research in physiological reactions during seances, or research into the neuro- and psycho-physiological connection between activation, intelligence, personality, and memory and achievements respectively. Student attitudes to education and research in the GDR are hardly comparable with those in the USA, therefore the establishment of laboratory situations with students poses no problem at all. In this way the students serve as "probandi" for psycho-physiological research, so that accepted criteria can be validated and the effectiveness of individual elements of Suggestopedia be measured. The results achieved are then incorporated into the next course design. This interrelationship between scientific research and practical application has proved to be successful. Some of the research results are subsequently published, for example in the "Wissenschaftliche Berichte". So far three volumes of research reports have been published, the most recent one in 1983.

In the GDR, Suggestopedia is not used either in elementary or secondary schools, but suggestope- 
dic foreign language courses are conducted in centres for continuing education. Like the students who take suggestopedic courses at the Institute for Mnemology, these continuing education students come from the working population, are aged from 18 to 55 years and have varying educational backgrounds. These courses are supported by the various ministries. Education is firmly in the hands of the government, and so is methodology. The languages taught in the Institute are Russian, English and Spanish. Under the guidance of the Institute, a controlled experiment with five control classes and one suggestopedic class in anatomy for future physiotherapists was conducted several years ago. Since its successful completion, anatomy has been taught suggestopedically several times.

Comparing Suggestopedia in the GDR with SALT in the USA or Australia I found several differences. In the GDR neither physical nor mental relaxation exercises precede the actual lesson; nor are visualisations and imagery used. Frequently the GDR students take off their shoes and put on slippers before they enter the classroom in order to emphasize the "livingroom atmosphere". Decoding, reviewing, elaborating and playing games or skits take place in the classroom, but there is a special room for the seances. I was invited to observe the Spanish lesson and was allowed to speak to the students during their break. The classrooms at the Institute are not particularly attractive. The students sit in reclining chairs in a square around the tables. The Spanish room is bright and airy, the English room is located in the cellar of the old building. It has poor lighting and ventilation, but some wood panelling on the walls gives it a special charm. The room for the seances, which is also used for the breaks, is full of atmosphere and serenity. It still has the appearance of a pre-war library which belonged to a wealthy family, with high dark-brown leather chairs, a large tiled stove, a heavy oak table, a wool carpet, landscape paintings on the walls, high old-fashioned windows, and so on. I observed a Spanish grammar seance in this room. I noticed how the teacher spoke with an irregular and therefore unpredictable three level intonation and to my surprise increased the speed of his reading until towards the end I could not understand a word anymore. The volume of the Baroque music was below the teacher's normal voice level. The research team at the Institute found that a speedup in the passive concert session from normal speaking speed to very fast not only enables the teacher to get more material across, but it increases retention. I detected no synchronisation of text and music, and no special attention was paid to breathing. The teacher began to increase the speed of his reading when the music changed from an adagio to an allegro, in other words, when the pulse of the music was faster than 60 beats per minute. At the end of a suggestopedic foreign language course the students are given a written and an oral test. At no time do their students present a so-called psycho-drama. I explained to the researchers the type of psycho-drama that I had used in my teaching. Their reaction was that their students were confronted with real life problems which they had to solve, not something as imaginary and unreal as my dramas. In the Spanish session which I was invited to observe on the following day I witnessed one such problem-solving skit. This skit dealt with three young people, two men and a woman, who had just arrived in a Cuban city and wanted a room in a hotel. The receptionist told them that he had only two rooms, not three. Each one of the three argued his/her point regarding his/her entitlement to a room. They used arguments one would not expect to hear in East Germany, that is one said that his father was the Minister for Culture, and he would not be pleased to hear that his son had not been treated with special consideration. However, his argument did not get him a room. This skit lasted for at least twenty minutes. Two groups of four students each played the skit simultaneously. One student-there were nine in the class-had to monitor the discussions and present the solutions at the end of the skit. The idea was that the three young people in the group became friends, the two men shared the room not as strangers anymore, since they had found out that they had all come to this city to help their comrades. Class sizes at the Institute are kept to between eight and ten students.

The students are selected from a large group of applicants - there were 300 applicants and only ten were chosen for the Spanish course which I observed. All applicants have to take two psychological tests. The examiners then look for ten applicants who have one criterion in common. The nature of the criterion was revealed neither to the students nor to me; in fact, the students were surprised to find out that they did have one thing in common, when I asked the question regarding 
selection. The selected ten obtain permission from their respective authorities at their place of work to study instead of going to work. Classes begin at $9 \mathrm{a} . \mathrm{m}$. and end at $12.45 \mathrm{p} . \mathrm{m}$. with a fifteen minute break. The concert sessions always take place at the end of the day and the students are encouraged to go home quietly. At bedtime they are supposed to read through the material of the day. They are advised to spend the afternoon engaged in cultural activities. The researchers agreed that that part of the programme could, of course, not be controlled. At present, a suggestopedic Spanish course at the Institute lasts for six weeks, with six classmeetings per week. The English course has been expanded to seven weeks, because, as the teacher concerned told me, the students like it so much that they wish to continue. When asked for what purpose they were studying the foreign language, they all said, "aus beruflichen Gründen", for job reasons. When asked what sort of work they did at their jobs, there were as many answers as students. During the midmorning break the students chat in the target language, with the teacher taking part in the conversation, over a cup of coffee for the "Cubans" and a cup of tea for the "English", the latter being taught British English. Obviously the two groups have their breaks at different times. Overall I found quite a lot of grammar on the blackboards, but no grammar posters on the walls. The students are given grammar sheets with paradigms and practice sentences. In the Spanish class the teacher and students spent about twenty minutes reading and explaining grammar points in the form of paradigms prior to the grammar seance. The teacher read the respective grammar rather dramatically without music, while the students followed his reading and made the occasional note or underlined something. When all was clearly understood, the students moved into the seance room for the passive concert. All students found suggestopedic teaching most enjoyable and effective. At first I was amazed to realize that none of them knew anything about the method and the theories behind it. But then it became clear to me that they were kept in ignorance on purpose to eliminate the expectancy of better learning which in itself can influence motivation and would thereby be detrimental to the validity of some psychophysiological research data. Whether or not the students who learn suggestopedically at other educational centres in East Germany are informed regarding the method I do not know. The students at the Institute were not familiar with the name Georgi Lozanov, the originator of the method. I told them about my work with Suggestopedia in Australia, and again I noticed their surprise at hearing that we, too, teach this way.

In the course of my discussions with faculty members at the Institute I found out that this Institute had its last contact with Dr Lozanov in 1982. Since then they have developed their own suggestopedic system, and have adapted it to their needs and in accordance with their own research results. Since 1982 the East German researchers have been in close contact with their Hungarian counterparts. The East Germans produce their own language textbooks. I examined a number of them and noticed that they update them quite frequently, again according to their needs and research. Already in elementary courses they use additional reading material. The chapters in the main textbooks clearly show a notional/functional approach. I got the impression that the students there are expected to develop practical creativity, survival skills, and not so much expansion of their personalities, an aspect we stress so much in Western Suggestopedia.

In 1973, at the educational centre of the collective Robotron in Leipzig, the first suggestopedic courses were conducted in Russian. Since 1977 English courses have been conducted as well. By 1978 more than 500 adults aged between 18 and 55 had taken suggestopedic courses. Up to 12 people are' admitted to a course, each course lasting for six weeks. Courses have been developed for three levels. For both languages taught, the teachers developed introductory courses to prepare the students for level one. In those introductory courses the students learn approximately 1000 lexical items. In this way the teachers make sure that the students of level one start at the same level. As far as course content is concerned, the preparation course and level one of the language course deal exclusively with everyday topics, that is notional/functional topics, and with the geographical and cultural situation of the Soviet Union and England respectively, as well as with normative grammar. Grammar is not stressed at all, although some grammatical structures are taught as they appear in the texts. Grammar is not taught for the sake of grammar.

In level two more general themes pertaining to science and technology. basic concepts of eco- 
nomic politics and general topics from the area of mathematical and electro-technology are dealt with. Only very difficult aspects of grammar, particularly in Russian, are taught.

In level three special topics in the area of technology, energy and commerce are dealt with linguistically. Grammar is no longer taught, only reviewed. On all levels, but particularly on level one, much attention is paid to phonetics, as they aim at a perfect command of cultured pronunciation. The students and teachers work with two sets of texts. One set is contained in the textbook which naturally carries some redundant vocabulary, and the other set is used for the seances, where this redundancy has been skilfully eliminated. Apart from linguists, subject specialists help with the writing of such texts. The text for the seances shows the target language and the translation, a list of the new vocabulary and a list of the new verbs, the latter because verbs play an important role in any language, therefore they receive special attention in the seances. The teachers at the collective Robotron call this the nucleus of the material. In addition other material has been produced which they call variable material, consisting for instance of texts to be translated into both languages, the target language and the mother tongue, interviews as well as grammatical exercises in the traditional fashion. Level one contains predominantly dialogues and descriptive texts, levels two and three monologue texts and lessons without a text at all, but in their place they have phrases and lexical items. These phrases serve the purpose of guided conversations and often highlight special grammatical points. Not all verbs of a lesson can be found in a verb list, but only those which are used frequently and those which lend themselves to grammatical demonstrations of their various forms. The exercises preceding the grammar seance in the Spanish lesson which I saw at the Institute dealt with such verbs as well.

It seems that other educational centres in the German Democratic Republic arrange their courses in a similar way to the ones I have just described, making allowances, of course, for different subjects. The Institute conducted a controlled experiment in 1972 at the School of Medicine teaching students anatomy in six courses. Each course had an equal number of experimental and control students, except course 6 , which had 48 suggestopedic students enrolled. The comparative results showed a decrease in teaching time in all five experimental courses, less time spent on homework in those suggestopedic courses where such data was collected and generally higher marks and no fail mark. The researchers also assessed the effectiveness of suggestopedic teaching versus conventional teaching of anatomy. In all suggestopedic courses and in all parts of the courses the effectiveness of the teaching was increased in varying degrees. They found that particularly the weaker students and those who showed complicated personality traits, especially the neurotic students, fared better with suggestopedic teaching than their counterparts in the conventionally taught classes. The sixth course in this project was taught by two teachers who each took 24 students. One of the teachers taught suggestopedically, the other taught in the traditional manner. This was clearly reflected in the achievements the two groups reached. While the first five pairs of classes had between 12 and 40 contact hours necessitated by the distribution of the various subjects within anatomy, course 6 was taught throughout the year in 109 hours. The fact that the results of course 6 were below the results of the other suggestopedic groups caused the researchers much heartsearching. A questionnaire filled in by the students gave some clues toward the explanation of the problem. It appeared that not enough tests were given in such a way that they would influence the students' attitude to learning in a positive and motivating way. Furthermore, course 6 went on for far too long, and the students who were at the same time exposed to conventional teaching in other subjects suffered from interference from other subjects. The latter became evident from the answers in the questionnaire. The researchers drew several conclusions from these experiments:

- Suggestopedic teaching can achieve the same learning results in a shorter time. It can even increase the results significantly.

- Inconsistent results may appear through unavoidable external interference. Such disturbing factors must therefore be eliminated.

- There is no subject area within anatomy which is in principle not suitable for suggestopedic teaching.

- Suggestopedic teaching can generally be integrated into a total course of studies. It can 
improve the student's attitude to learning, his/her ability and independence.

- All elements of suggestopedic teaching must be observed in order to achieve maximum results.

It seems that the researchers in the GDR to date have not taught other subjects by suggestopedic methods. The researchers mentioned in their discussions with me those courses in foreign languages and those in anatomy that I have discussed in this paper. Specific research is continuing under the auspices of the University and various Government Ministries. Such cooperation between academic institutions and the government, whereby the latter is willing to bear the financial burden, must bring interesting results. In the GDR, Suggestopedia is organised and in firm and competent hands, unlike the situation in the West, where so many people do their own thing and make unsubstantiated claims and thereby do more harm than good to a potentially wonderful method.

In my view every country should establish a research set-up similar to the one in the Institute of Mnemology at the University of Leipzig. We could then validate claims and compare results on a much larger scale, we could refine the method and its adaptations for each country and thereby learn from and about each other and we could develop it further. Suggestopedia could then become universal and would no longer be dominated by any country East or West of the Iron Curtain.

When one accepts the right of every human person to be intelligent, the focus of one's existence changes more radically than may be obvious at first glance.

This proposition has a bearing on the family, the State, the international community, and even the concepts of man and history. It represents an ideological revolution. In changing man by making him more intelligent, we transform all of society. 